\title{
PRECISE U-Pb ZIRCON DATING OF THE SYENITE PHASE FROM THE DITRĂU ALKALINE IGNEOUS COMPLEX
}

\author{
PANĂ DINU ${ }^{1}$, BALINTONI IOAN ${ }^{2}$, HEAMAN LARRY ${ }^{3}$
}

\begin{abstract}
The Ditrău igneous complex represents the largest alkaline intrusion in the Carpathian-Pannonian region consisting of a plethora of rock types formed by complicated magmatic and metasomatic processes. A detailed U-Pb zircon age study is currently underway and the results for the syenite intrusion phase is reported herein. The U-Pb zircon emplacement age of the syenite of 229.6 $+1.7 /-1.2$ Ma documents the quasi-contemporaneous production and emplacement of the gabbro and syenite magmas. We suggest that the syenite and associated granite formed by crustal melting during the emplacement of the mantle derived gabbroic magma around 230 Ma. The thermal contact aureole produced by the Ditrău alkaline igneous complex constrains the main tectonism recorded by surrounding metamorphic lithotectonic assemblages to be preLadinian.
\end{abstract}

Key words: Ditrău alkaline intrusion, syenite, U-Pb data

\section{INTRODUCTION}

The Ditrău Alkaline Intrusive Complex is emplaced within the metamorphic basement rocks at the interior of the East Carpathians. It is characterized by a peculiar petrographic-mineralogical constitution that includes large series of ultramafic to acid silica-oversaturated and undersaturated alkaline rocks. The complicated internal structure of the complex includes both massive and foliated rocks.

Various petrologic models were advanced in the course of over 100 years of investigations by several generations of geologists. Proposed models range from metasomatic to magmatic origin, and from emplacement in a single magmatic event to multiple successive magmatic pulses (Streckeisen, 1952; Codarcea et al., 1958; Pál-Molnár, 1994; Kräutner and Bindea, 1998).

\footnotetext{
${ }^{1}$ Alberta Geological Survey, 4th Floor, Twin Atria Building, 4999-98 Avenue, Edmonton, Alberta, Canada T6B 2X3

2 Department of Mineralogy, "Babeş-Bolyai" University, 3400 Cluj-Napoca, Cluj, Romania

${ }^{3}$ Department of Earth And Atmospheric Scinces, University of Alberta, Edmonton, Alberta, Canada, TGG 2E3
} 
Assumed or inferred ages range from Paleozoic to Neogene (lonescu et al., 1966; Földvari, 1946). The most recent compilation of existing isotope dates (Kräutner and Bindea, 1998) advocates a "three stage" model derived from the succession of events proposed by Streckeisen and Hunziger (1974). All isotope dates obtained from a large variety of rocks in the course of the last three decades by different authors using different isotope systems $\left({ }^{40} \mathrm{Ar} /{ }^{39} \mathrm{Ar}\right.$, K-Ar, and $\left.\mathrm{Rb} / \mathrm{Sr}\right)$ were grouped in frequency intervals with the resulting maxima interpreted to have direct geochronological significance. The following ages were assigned to Streckeisen's succession of events (Kräutner and Bindea, 1998):

c.230 Ma for the earliest gabbro and diorite;

c. $215 \mathrm{Ma}$ for the syenite and associated granit; aureole.

c. $165 \mathrm{Ma}$ for the nepheline syenite and tinguaite veins and hornfels

${ }^{40} \mathrm{Ar} /{ }^{39} \mathrm{Ar}$ plateau ages exist only for hornblende concentrates from diorite (Dallmeyer et al., 1997) and indicate ages of 231 and $227 \mathrm{Ma}$. For these rocks existing K-Ar dates are spread over a range of 120 Ma with the highest frequency in the 160-150 Ma range (see compilation by Kräutner and Bindea, 1998). In spite of the obvious inconsistency, emplacement ages for the syenite and nepheline syenite were assigned based on discretionary interpretation of frequency hystograms with K-Ar dates scattered over 100 $\mathrm{Ma}$. Although the frequency maximum for the nefeline syenite is in the 150$160 \mathrm{Ma}$ range and that of the syenite shows two maxima at 140-130 and 120-110 Ma, the syenite was interpreted to be $55 \mathrm{Ma}$ older than the nepheline syenite. These striking inconsistencies make the igneous evolution proposed in the aforementioned compilation highly suspect.

A systematic $\mathrm{U}-\mathrm{Pb}$ zircon age study is currently underway in an attempt to constrain the timing of emplacement of the DAIC. We report here the first precise U-Pb zircon age on a key rock type of the DAIC, the Ditrău syenite.

\section{GEOLOGICAL SETTING}

The Ditrău alkaline igneous complex (DAIC) is located on the inner margin of the Carpathian orocline, immediately north of the town of Gheorghieni, East Carpathians (Fig 1). It has a domal shape and an elliptical section $(20 / 15 \mathrm{~km})$ with the long axis parallel to the local trend of the orogen.

The DAIC intrudes metamorphic basement rocks assigned to the Middle Cretaceous Bucovinian Nappe (Săndulescu, 1984). From west to east and from lower to upper, the following units of metamorphic rocks were intruded and thermally affected by the DAIC: the Rebra, Negrişoara, Tulgheş, Mândra, and Rarău lithotectonic assemblages (Balintoni, 1981). The Rebra and Rarău lithotectonic assemblages include medium-grade rocks with local discrete retrogression, the Negrişoara and Mândra assemblages are 
pervasively retrogressed and the Tulgheş assemblage consists almost exclusively of low-grade rocks. Each lithotectonic assemblage was interpreted to represent a Variscan thrust sheet (e.g., Balintoni, 1981,1997).

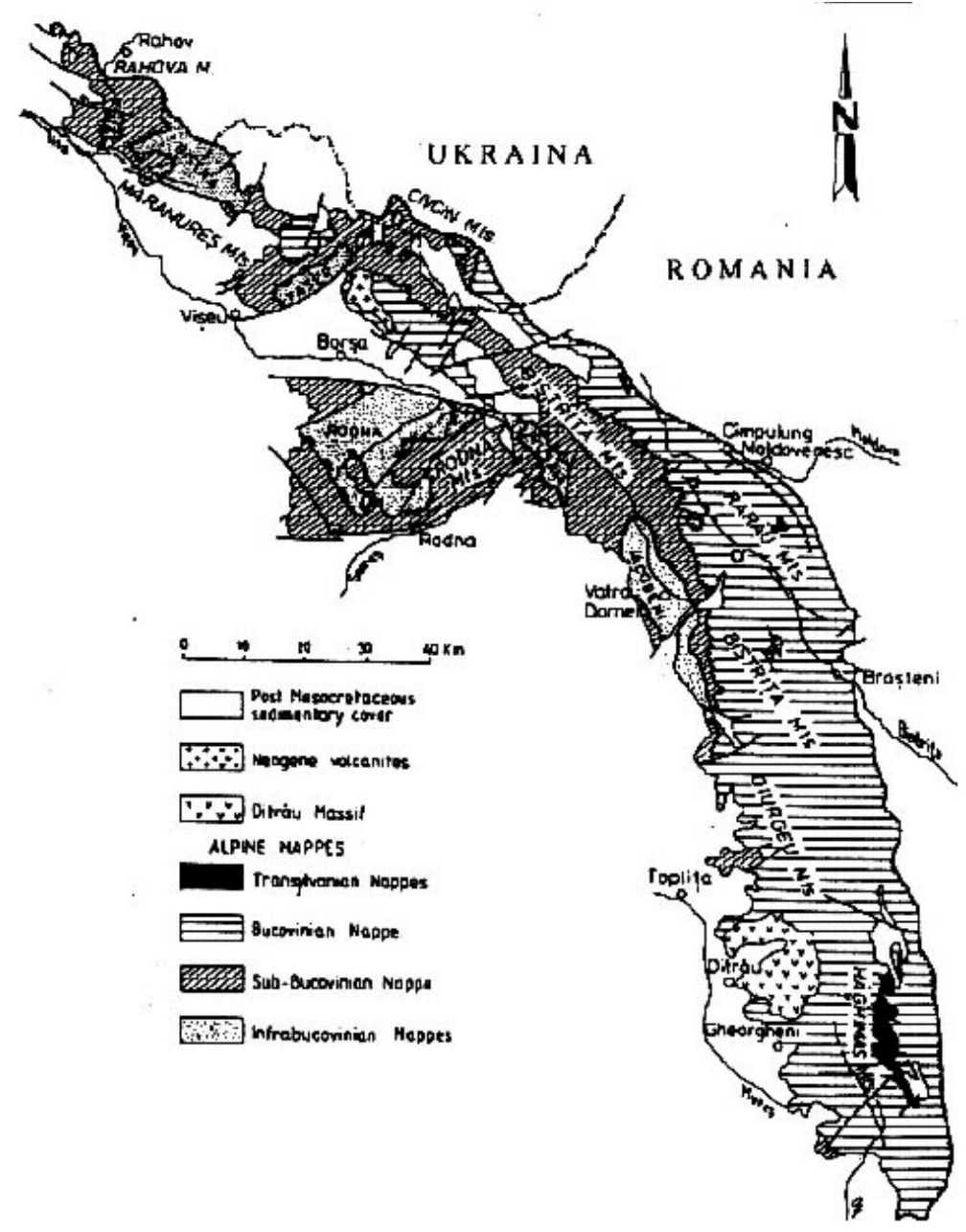

Fig. 1. Location of the Ditrău Massif in the East Carpathians Crystalline Zone

Alternatively, the symmetrical distribution of strain and retrogression may define the infrastructure of a crustal scale transcurrent shear zone with the axial zone along the Tulgheş lithotectonic assemblage (Pană and Erdmer, 1994). 
The DAIC produced a thermal aureole up to $2 \mathrm{~km}$ wide on surrounding Pre-Alpine metamorphic rocks (Fig. 2). Parts of the DAIC are unconformably overlain by andesitic pyroclastics with some interbedded basalt-andesite lava flows from the Neogene Harghita-Călimani and by Pliocene to Pleistocene lignite-bearing lacustrine deposits of the Jolotca basin (Rădulescu et al., 1973).

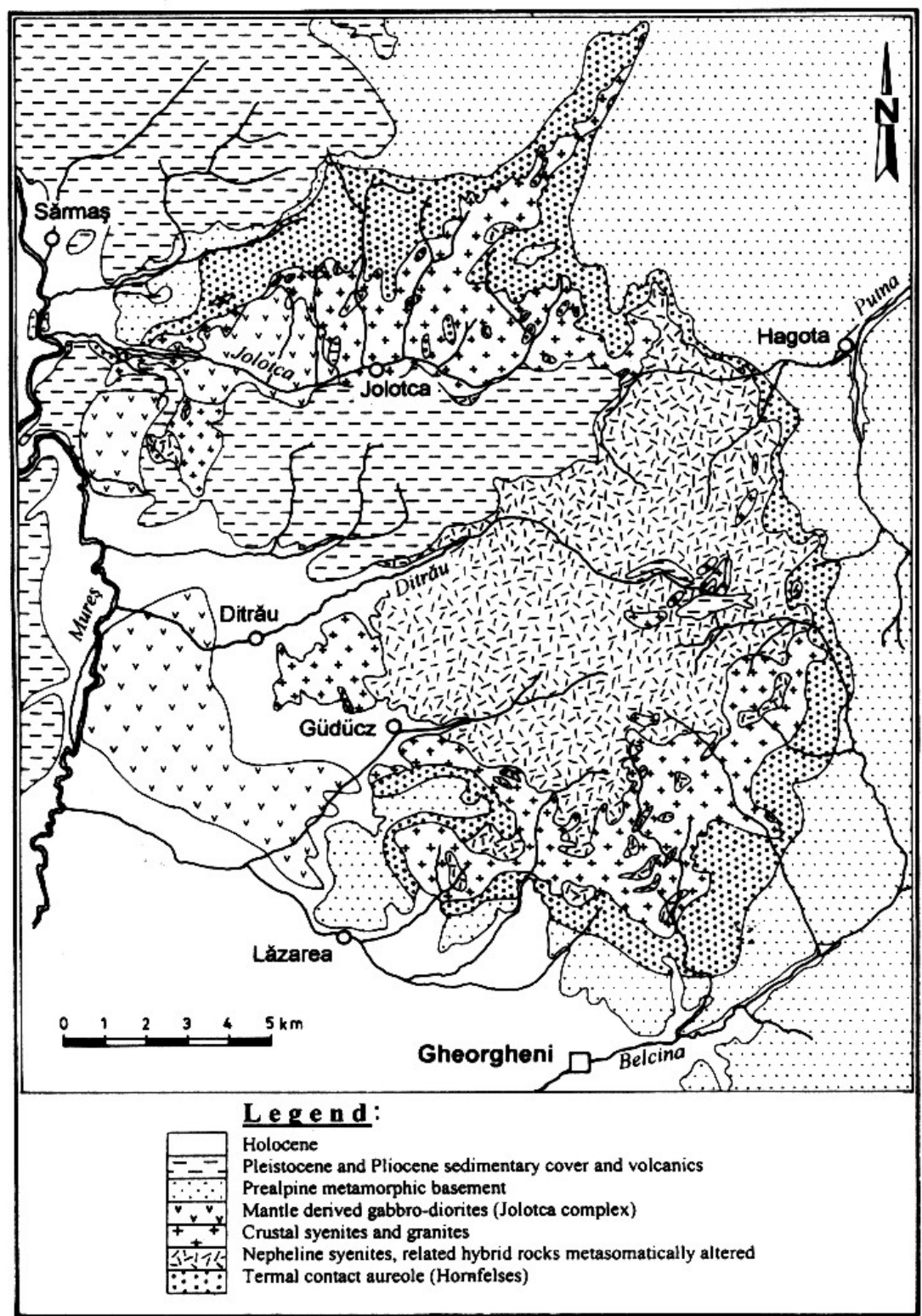

Fig.2. The structure of the Ditrău Massif 
The DAIC consists of rocks of extremely varied mineralogy, chemistry, and texture and presents a particularly complicated structure. A vague ring structure (Streckeisen and Hunziker, 1974) includes granitic rocks at margins mostly in the north, followed by commonly foliated syenite and three complexes of dioritic rocks, one in the northwest, a second in the centre and a third at the western margin. The rocks of these complexes are particularly heterogeneous, commonly foliated and at places distinctly schistose. Mafic rocks are intermingled with bands and veins of syenite and nepheline syenite and have undergone widespread metasomatic changes and hybridization phenomena (Codarcea et al., 1958). The eastern part of the massif consists mainly of nepheline syenite either fresh and light coloured or reddish and strongly hydrothermally altered. The fresh nepheline syenite are intruded by tinguaite dikes and veinlets of sodalite. Lamprophyre dykes with sharp limits are widespread and especially in the dioritic complexes.

Cross-cutting relationships suggest the following igneous evolution (Streckeisen and Hunziker, 1974):

- intrusion of gabbroic and dioritic magmas,

- intrusion of syenitic magmas and formation of granites by silicarich crust assimilation,

- nefelinite-bearing melts $+\mathrm{CO}_{2}$ wich produced widespread hybridization and metasomatic changes especially in the dioritic complexes,

- late nepheline syenite aplite and pegmatite, and lamprophyre.

The DAIC is surrounded by a thermal contact aureole with biotite, cordierite, andalusite, corundum, rarely spinel and alkali amphibole, occasionally chloritoid hornfelses at the immediate contact, followed by spotted and knotted schists more distant from the contact.

\section{PREVIOUS ISOTOPE DATING}

The first K-Ar dates were interpreted to indicate Pre-Jurassic (196 Ma) emplacement age for the hornblendite and Late Jurassic-Neocomian (140$120 \mathrm{Ma}$ ) emplacement for the syenite and granite (Bagdasarian, 1972). Biotite from the nepheline syenite, tinguaite and contact aureole rocks yielded KAr dates of 160 - $150 \mathrm{Ma}$ (Streckeisen and Hunziker, 1974). K-Ar ages ranging from 189 to $115 \mathrm{Ma}$ were interpreted to indicate an emplacement age of the DAIC at $135 \mathrm{Ma}$ (Kräutner et al., 1976). K-Ar mineral and wholerock ages ranging from 200 to $120 \mathrm{Ma}$ and a ${ }^{40} \mathrm{Ar} /{ }^{36} \mathrm{Ar}-{ }^{40} \mathrm{~K} /{ }^{36} \mathrm{Ar}$ mineral isochrone of 138.7 +/-3 Ma were reported by Mânzatu et al. (1980 and 1981).

Whole rock $\mathrm{Rb}-\mathrm{Sr}$ ages were interpreted to record an ultrabasic intrusion at $200 \mathrm{Ma}$ followed by a syenite intrusion at about $160 \mathrm{Ma}$ (Popescu, 1985). The wide ranges of existing $\mathrm{K}-\mathrm{Ar}$ and $\mathrm{Rb}-\mathrm{Sr}$ data were reinterpreted by Zincenco (1991) to record a long lasting continuous cooling process that involved emplacement of the DAIC at $171 \mathrm{Ma}$, ending of the pneumatholitic 
stage at $165 \mathrm{Ma}$ and ceasing of the hydrothermal phase at $154 \mathrm{Ma}$. Additional $\mathrm{Rb}-\mathrm{Sr}$ whole rock isochrone data were interpreted to record DAIC emplacement at $201 \mathrm{Ma}$ (Zincenco et al., 1994).

Pál-Molnár and Arva-Sos (1995) recorded K-Ar ages of $237-216 \mathrm{Ma}$ from hornblendite, (4 anlyses on amphybole), and proposed a two stage evolution with a Middle Triassic to Lower Jurassic intrusion of hornblendites, nephelin-syenite and granites followed by Middle Jurassic to Lower Cretaceous emplacement of syenite, alkali-felspar syenite and hybrid diorites.

${ }^{40} \mathrm{Ar} /{ }^{39} \mathrm{Ar}$ plateau ages of 231 and $227 \mathrm{Ma}(2$ analyses on hornblende) were recorded on a horblenditic and gabbroic sample and related to a Middle Triassic extension phase (Dallmeyer et al., 1997).

\section{U-Pb ZIRCON DATA}

In order to constrain the emplacement age of the Ditrău alkaline igneous complex we are currently undertaking a systematic U-Pb zircon study of key lithotypes selected based on their crosscutting relationships. Field observations indicate that syenitic rocks are younger than various mafic rocktypes. One sample of slightly foliated medium-grained syenite was collected from the right bank of the Jolotca Creek approximately $200 \mathrm{~m}$ south of the bridge at the western end of Jolotca village (Fig. 2). Microclineperthite and oligoclase form larger tabular grains oriented parallel to foliation and are welded by smaller grains of microcline and albite. Biotite is common amphibole and aegirine-augite are rare. Secondary green-biotite, epidote and titanite are frequent and accessory magnetite, zircon, apatite. Four zircon fractions were analysed using the isotope dilution thermal ionization (TIMS) method at the University of Alberta.

\subsection{Analytical procedure}

One sample of approximately 12 kilograms was pulverized to a fine powder with a jaw crusher and Bico disc mill and passed over a Wilfley table to concentrate heavy minerals. Zircon was separated using heavy liquid and magnetic mineral separation (see Heaman and Machado, 1992). Individual zircon selection using a microscope was made to avoid grains with cracks, alteration, inclusions, or other imperfections, and multi-grain fractions were collected on the basis of distinct optical features and grain quality. All zircon fractions were washed prior to dissolution. Zircon fractions were spiked with a mixed ${ }^{205} \mathrm{~Pb}-{ }^{235} \mathrm{U}$ tracer solution (see Krogh and Davis, 1975). Sample dissolution and the extraction of $\mathrm{Pb}$ and $\mathrm{U}$ followed closely the procedure of Krogh (1973). Pb and $U$ blanks were 3.5 $\mathrm{pg}$ and $0.1 \mathrm{pg}$, respectively. $\mathrm{Pb}$ and $\mathrm{U}$ were loaded onto outgassed, single Re filaments in a silica gel-phosphoric acid mixture and analysed using a VG 354 mass spectrometer. $\mathrm{Pb}$ isotopic ratios were measured using a 
single Faraday cup collector. For a typical $\mathrm{Pb}$ load of $10 \mathrm{ng}$, the average beam intensity at mass 206 (at $\left.1,450^{\circ} \mathrm{C}\right)$ was $0.5 \times 10^{-11} \mathrm{~A}\left(10^{11} \mathrm{ohm}\right.$ resistor). All $\mathrm{Pb}$ and $\mathrm{U}$ isotopic data were corrected for mass fractionation using factors of $+0.088 \%$ /amu (atomic mass unit) for $\mathrm{Pb}$ and $+0.155 \%$ /amu for $\mathrm{U}$, from replicate analysis of the NBS-SRM 981 common Pb and NBS-SRM U 500 standards. For isotopic ratios measured with a Daly photomultiplier detector, a Daly-Faraday empirical conversion factor of $+0.13 \% / \mathrm{amu} \mathrm{Pb}$ and + 0.15/amu $U$ was used.

Errors associated with $\mathrm{Pb} / \mathrm{U}$ and ${ }^{207} \mathrm{~Pb} /{ }^{206} \mathrm{~Pb}$ ratios were calculated with an in-house program that numerically propagates known sources of error. Initial common $\mathrm{Pb}$ isotopic composition was calculated using the model of Stacy and Kramers (1975). The regression line and error associated with age determination (quoted at the 95\% confidence level) were calculated using the ISOPLOT software (version 2.12, K. Ludwig, United States Geological Survey). Decay constants used for ${ }^{235} \mathrm{U}(9.8485 \mathrm{x}$ $\left.10^{-10} \mathrm{yr}^{-1}\right)$ and ${ }^{238} \mathrm{U}\left(1.55125 \times 10^{-10} \mathrm{yr}^{-1}\right)$ and the isotopic composition of uranium (137.88) follow Jaffey et al. (1971) and the IUGS Subcommission on Geochronology (Steiger and Jäger, 1977).

\subsection{Results}

Four fractions of transparent zircon grains from the Ditrău syenite were analyzed (fractions 2 to 5 ).

Fraction 2 consisted of 22 large fragments of very pale yellow with brown stains transparent zircon grains. Fraction 3 consisting of the best 22 zircon grains with colourless, transparent inclusions was slightly abraded.

Fraction 4 consisted of 40 colourless irregular transparent zircon fragments and fraction 5 included 32 irregular medium to large fragments of colourless transparent zircon selected as "second best" and slightly abraded.

All fractions yielded slightly discordant data points (Fig. 3.) with the abraded fractions showing the smallest discordance of $1.9 \%$ and $-1.3 \%$ (Table 1). Fraction 5 contained the smallest amount of $U$ and Th.

Regression lines through fractions $2,3,4$, and 5 and through fractions 3, 4, and 5 intersect concordia at $229.6 \mathrm{Ma}$ with similar errors and MSWD of 1.7 and 1.8 respectively. A third regression line through selected data points 2, 3, and 5 intersects concordia at 229.7 Ma with MSWD of 0.054 . The emplacement age of the Ditrău syenite is considered to be well constrained by all 4 fractions analysed at $229.6+1.7 /-1.2 \mathrm{Ma}$ (MSWD =1.7). 
PANĂ DINU, BALINTONI IOAN, HEAMAN LARRY

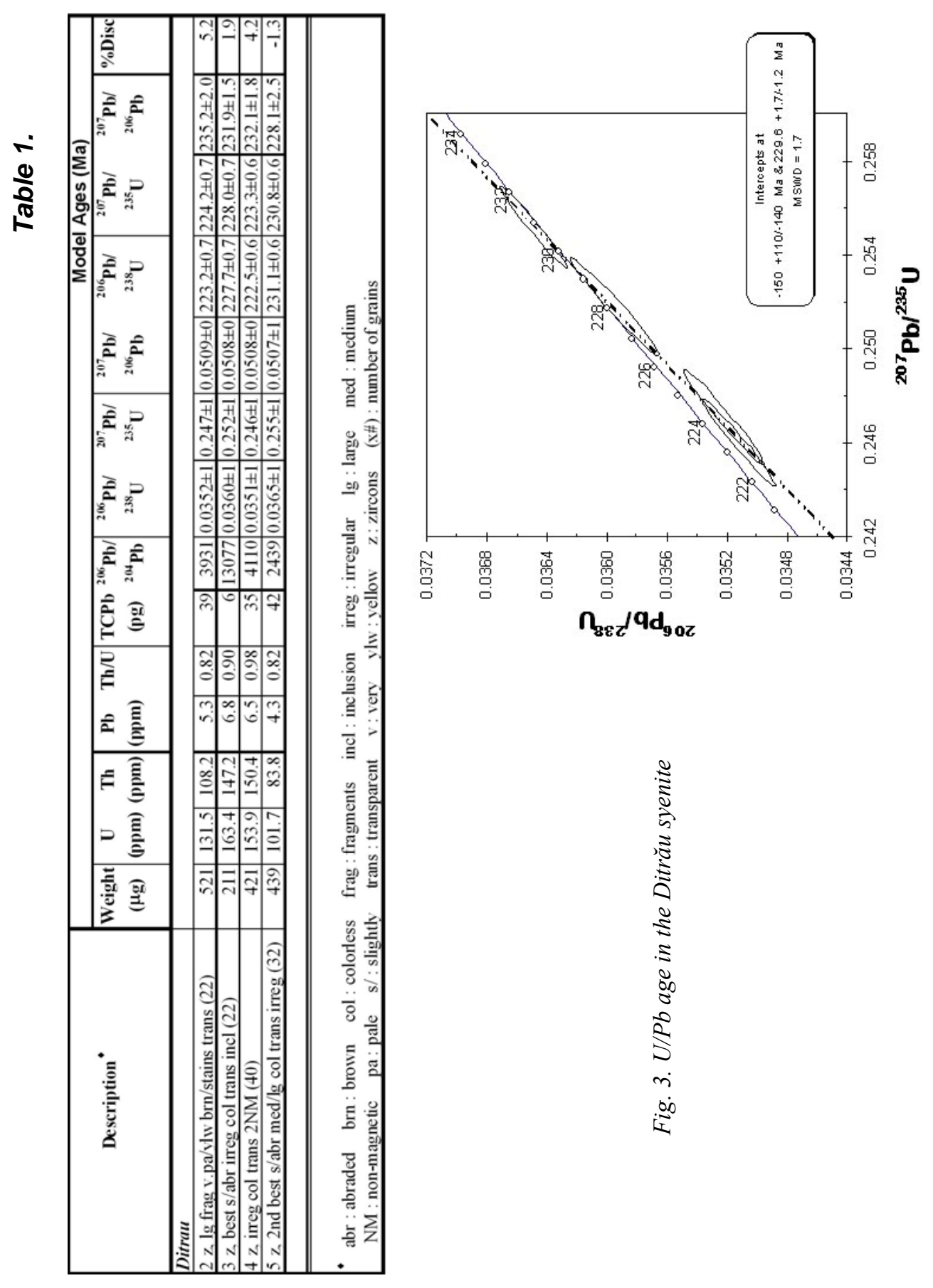




\section{CONCLUSIONS}

1. The discretionary interpretation of $\mathrm{K}-\mathrm{Ar}$ dates from the Ditrau alkaline intrusive complex as emplacement ages and/or ages of tectonism (Kräutner and Bindea, 1998) resulted in a highly suspect evolutionary model that advocated three igneous pulses within the same spot over a 70 Ma interval.

Our first precise U-Pb zircon age of $229.6+1.5 /-1.7 \mathrm{Ma}$ for the Ditrau syenite matches within error the hornblende ${ }^{40} \mathrm{Ar} /{ }^{39} \mathrm{Ar}$ dates obtained from the diorite complex and hints to a relatively short magmatic evolution of the DAIC, most likely within the Ladinian time. The syenite was emplaced at about the same time as the mantle-derived gabbro and diorite. This validates Strekeisen's (1975) original interpretation and disproves the speculations of a 15 Ma time gap between the emplacement of gabbro and of syenite (Kräutner and Bindea, 1998).

Modern ${ }^{40} \mathrm{Ar} /{ }^{39} \mathrm{Ar}$ hornblende plateau ages (Dallmeyer, 1997) are clearly geologically meaningful. Slightly younger K-Ar ages of 234.7-216 Ma for hornblendite (Pál-Molnár and Árva-Sos, 1995) are remarkably close and suggest loss of small amounts of Ar. Other K-Ar dates spread over a large interval likely record variable Ar degassing of Ladinian rocks during subsequent tectonism and should be considered cautiously.

2. The DAIC contact aureole overprinting surrounding schists and gneisses constrains the foliation development in the East Carpathians metamorphic basement to be pre-Middle Triassic. Thrust contacts inferred between the Rebra, Negrişoara, Tulgheş, Mândra, Rarău lithotectonic assemblages are constrained to be pre-Alpine as previously proposed by Balintoni (1981). The extreme strain concentration and retrogression recorded by the Tulgheş lithotectonic assemblage (Pană and Erdmer, 1994) is also constrained to be pre-Alpine. The foliated rocks common within the DAIC, indicate predominantly an intrusion flowage, defining a mymetic fabric, paralel to pre-Alpine attitude of the metamorphic foliation. Basement-cover relationships elsewhere in the East Carpathians constrain the only major Alpine tectonism to be Cretaceous, pre-Cenomanian (Săndulescu, 1984). Noteworthy, most K-Ar ages from the DAIK range between 160 and $100 \mathrm{Ma}$. A case can be made that these dates record Ar degassing due to middle Cretaceous shearing.

We conclude that basement units intruded by the DAIC were juxtaposed before the Ladinian time, most likely during the Variscan tectonism, and recorded together penetrative Alpine strain.

\section{ACKNOWLEDGEMENTS}

The research for this paper was partially supported of the grant 46.174/1997 theme 16, accorded by World Bank. 


\section{REFERENCES}

1. Bagdasarian, G. P., (1972), On the absolute age of some igneous and metamorphic rocks of the Ditrau massif and Banat Mts. in Romania, St. Cerc. Geol., Geofiz., Geogr., Seria Geologie, 17, 1, 13-21

2. Balintoni, I., (1981), The importance of the Ditrau alkaline massif emplacement moment for the dating of the basement overthrusts in the East Carpathians. Rev. Roum. Geol., Geophys., Geogr., serie Geologie, 25, 89-94

3. Balintoni, I., (1997), Geotectonica terenurilor metamorfice din România, Ed. Carpatica, 176, Cluj Napoca

4. Codarcea A., Dessila-Codarcea, M., Ianovici, V., (1958), Structure géologique du massif des roches alcalines de Ditrau, Rev. Roum. Géol. Géogr., 2, 1, 1-135

5. Dallmeyer, R. D., Kräutner, H. G., Neubauer, F., (1997), Middle-Late Triassic 40Ar/39Ar hornblende ages for early intrusions within the Ditrau alkaline massif, Romania: implications for Alpine Rifting in the Carpathian orogen. Geologica Carpathica, 48, 6, 347-352.

6. Földvári, A., (1946), Age and contact-metamorphic effects of the nefeline syenite stock of Ditró (Transylvania). Rel. An. Inst. Geol. Hung. (Besz. Magy. Àll. Fòldt. Int), B. disp. (Budapest), 8, 1-2, 11-32.

7. Heaman, L.M., Machado, N., (1992), Timing and origin of midcontinental rift alkaline magmatism, North America:evidence from the Coldwell Complex, Contr. Miner. Petr., 110, 289-303.

8. Ionescu, J., Tiepac, I., Udrescu, C., (1966), Dating of absolute ages by the Pb- $\alpha$ method. Com. Geol. Stud. Tehn. Econ., Seria B (Bucureşti), 44, 55-63.

9. Jaffey, A.H., Flynn, K.F., Glendenin, L.E., Bentley, W.C., Essling, A.M., (1971), Precison measurements of half-lives and specific activities of 235U/238U. Phys. Rev., C4, 1889-1906.

10. Kräutner, H.G., Kräutner, FI., Tănăsescu, A., Neacşu, V., (1976), Interpretation des âges radiometriques $K$-Ar pour les roches métamorphiques régénérées. Un exemple - les Carpates Orientales. An. Inst. Geol. Geofiz., 50, 167-229.

11. Kräutner, H.G., (1988), Interregional correlations, in Zoubek V., Cogné, J., Kozhoukharov, D., (Eds.): Precambrian in Younger Fold Belts, 853-862, John Wiley \& Sons, New York.

12. Kräuner, H.G., Bindea, G., (1998), Timing of the Ditrău Alkaline Intrusive Complex. Abstr. $16^{\text {th }}$ Congr. Carp.-Balk. Geol. Ass. (Wien), 310.

13. Kräuner, H.G., Bindea, G., (1998), Timing of the Ditrău Alkaline Intrusive Complex Eastern Carpathians, Romania. Slovak Geol. Mag., 4, 4 (1988), 213-221.

14. Krogh, T.E., (1973), A low-contamination method for hydrothermal decomposition of zircon and extraction of $U$ and $\mathrm{Pb}$ for isotopic age determinations, Geochim. Cosmochim. Acta, 37, 485-449.

15. Krogh, T.E., Davis, G.C., (1975), The production and preparation of ${ }^{205} \mathrm{~Pb}$ for use as tracer for isotope dilution analyses. Carnagie Inst. Washington Yearb., 74, 416-417

16. Mânzatu, S., Ardeleanu, P., (1980), Detailed radiometric research in the Ditrau massif (manuscript), Arch. IPEG "Harghita" (Miercurea-Ciuc). 
PRECISE U-Pb ZIRCON DATING OF THE SYENITE PHASE FROM THE DITRĂU ...

17. Mânzatu, S., Vâjdea, E., Romanescu, O., Iosipcenco, N., (1981), K-Ar ages of the Ditrau massif (manuscript), Arh. IGG Bucureşti

18. Pál-Molnar, E., Árva-Sós, E., (1995), K/Ar radiometric dating on rocks from the northern part of the Ditró syenite massif and its perogenetic implications. Acta. Min. Petr. Szege (Szeged) 36, 101-116.

19. Pană, D., (1998), Petrogenesis and Tectonics of the Basement Rocks of the Apuseni Mountains: Significance for the Alpine Tectonics of the CarpatianPannonian Region. Ph.D. Thesis, Univ of Alberta, Canada

20. Pană, D., Erdmer, P., (1994), Alpine crustal shear zones and pre-Apline basement terranes in the Romanian Carpathians and Apuseni Mountains. Geology, 22, 807-810.

21. Popescu, G., (1985), Rb-Sr geochronological data on rocks of the Ditrau Massif (in romanian, manuscript). Arch. GEOLEX Harghita (Miercurea Ciuc).

22. Rădulescu, D.P., Peltz, S,. Stanciu, C., (1973), Neogene Volcanism in the East Carpathians (Călimani-Gurghiu-Harghita Mts.), Sym. Volc., Metall., Exc. 2AB. Guidebook series, Geol. Inst., Bucharest, 12, 69 p.

23. Săndulescu, M., (1984), Geotectonica României, Ed. Tehn., Bucureşti, 336 p.

24. Stacey, J.S., Kramers, J.D., (1975), Approximation of Terrestrial Lead Isotope Evolution by a Two Stages Model. Earth. Plan. Sci. Lett., 26, 207-221.

25. Steiger, R.H., Jäger, E., (1977), Subcomission on Geoghronology: Convention on the Use of Decay constants in Geo- and Cosmochronology. Earth. Planet. Sci. Lett., 36, 359-467

26. Streckeisen, A., (1952), Das Nephelnsyenit-Massiv von Ditro (Siebenbürgen): Teil I. Schweiz. Min. Petr. Mitt., 32, 251-309.

27. Streckeisen, A., Hunziker, J.C., (1974), On the origin and age of the nephelin-syenite massif of Ditró (Transylvania, Romania). Schweiz. Min. Petr. Mitt., 54, 1, 59-77

28. Zincenco, D., (1996), Rb-Sr contributions to the chronology of the Ditrau massif, Anal. Univ. Bucureşti.

29. Zincenco, D., Petrescu, M., Popescu, C., Prodănescu, I, Zincenco, C., (1994), Age and petrology of the Ditrau massif: Rocks of the enveloping facies. (manuscript) Arch. Soc. Prosp. Bucureşti 